NASA/TM—2013-218074

\title{
Updated Assessment of an Open Rotor Airplane Using an Advanced Blade Design
}

Eric S. Hendricks, Jeffrey J. Berton, William J. Haller, and Michael T. Tong Glenn Research Center, Cleveland, Ohio

Mark D. Guynn

Langley Research Center, Hampton, Virginia 


\section{NASA STI Program . . . in Profile}

Since its founding, NASA has been dedicated to the advancement of aeronautics and space science. The NASA Scientific and Technical Information (STI) program plays a key part in helping NASA maintain this important role.

The NASA STI Program operates under the auspices of the Agency Chief Information Officer. It collects, organizes, provides for archiving, and disseminates NASA's STI. The NASA STI program provides access to the NASA Aeronautics and Space Database and its public interface, the NASA Technical Reports Server, thus providing one of the largest collections of aeronautical and space science STI in the world. Results are published in both non-NASA channels and by NASA in the NASA STI Report Series, which includes the following report types:

- TECHNICAL PUBLICATION. Reports of completed research or a major significant phase of research that present the results of NASA programs and include extensive data or theoretical analysis. Includes compilations of significant scientific and technical data and information deemed to be of continuing reference value. NASA counterpart of peer-reviewed formal professional papers but has less stringent limitations on manuscript length and extent of graphic presentations.

- TECHNICAL MEMORANDUM. Scientific and technical findings that are preliminary or of specialized interest, e.g., quick release reports, working papers, and bibliographies that contain minimal annotation. Does not contain extensive analysis.

- CONTRACTOR REPORT. Scientific and technical findings by NASA-sponsored contractors and grantees.
- CONFERENCE PUBLICATION. Collected papers from scientific and technical conferences, symposia, seminars, or other meetings sponsored or cosponsored by NASA.

- SPECIAL PUBLICATION. Scientific, technical, or historical information from NASA programs, projects, and missions, often concerned with subjects having substantial public interest.

- TECHNICAL TRANSLATION. Englishlanguage translations of foreign scientific and technical material pertinent to NASA's mission.

Specialized services also include creating custom thesauri, building customized databases, organizing and publishing research results.

For more information about the NASA STI program, see the following:

- Access the NASA STI program home page at http://www.sti.nasa.gov

- E-mail your question to help@sti.nasa.gov

- Fax your question to the NASA STI Information Desk at 443-757-5803

- Phone the NASA STI Information Desk at 443-757-5802

- Write to: STI Information Desk NASA Center for AeroSpace Information 7115 Standard Drive Hanover, MD 21076-1320 
NASA/TM-2013-218074

AIAA-2013-3628

\section{Updated Assessment of an Open Rotor Airplane Using an Advanced Blade Design}

Eric S. Hendricks, Jeffrey J. Berton, William J. Haller, and Michael T. Tong Glenn Research Center, Cleveland, Ohio

Mark D. Guynn

Langley Research Center, Hampton, Virginia

Prepared for the

49th Joint Propulsion Conference and Exhibit

cosponsored by AIAA, ASME, SAE, and ASEE

San Jose, California, July 14-17, 2013

National Aeronautics and

Space Administration

Glenn Research Center

Cleveland, Ohio 44135 


\section{Acknowledgments}

The work presented in this paper was supported by NASA's Fixed Wing Project. The authors would like to thank General Electric and Federal Aviation Administration's Continuous Lower Energy, Emissions and Noise (CLEEN) Program for providing access to advanced counter-rotating propeller data in support of this study.

This report is a formal draft or working paper, intended to solicit comments and ideas from a technical peer group.

This report contains preliminary findings, subject to revision as analysis proceeds.

Trade names and trademarks are used in this report for identification only. Their usage does not constitute an official endorsement, either expressed or implied, by the National Aeronautics and Space Administration.

Level of Review: This material has been technically reviewed by technical management.

Available from

NASA Center for Aerospace Information 7115 Standard Drive

Hanover, MD 21076-1320
National Technical Information Service 5301 Shawnee Road Alexandria, VA 22312 


\title{
Updated Assessment of an Open Rotor Airplane Using an Advanced Blade Design
}

\author{
Eric S. Hendricks, Jeffrey J. Berton, William J. Haller, and Michael T. Tong \\ National Aeronautics and Space Administration \\ Glenn Research Center \\ Cleveland, Ohio 44135 \\ Mark D. Guynn \\ National Aeronautics and Space Administration \\ Langley Research Center \\ Hampton, Virginia 23681
}

\begin{abstract}
Application of open rotor propulsion systems (historically referred to as "advanced turboprops" or "propfans") to subsonic transport aircraft received significant attention and research in the 1970s and 1980s when fuel efficiency was the driving focus of aeronautical research. Recent volatility in fuel prices and concern for aviation's environmental impact have renewed interest in open rotor propulsion, and revived research by NASA and a number of engine manufacturers. Over the last few years, NASA has revived and developed analysis capabilities to assess aircraft designs with open rotor propulsion systems. These efforts have been described in several previous papers along with initial results from applying these capabilities. The initial results indicated that open rotor engines have the potential to provide large reductions in fuel consumption and emissions. Initial noise analysis indicated that current noise regulations can be met with modern baseline blade designs. Improved blades incorporating low-noise features are expected to result in even lower noise levels. This paper describes improvements to the initial assessment, plus a follow-on study using a more advanced open rotor blade design to power the advanced single-aisle transport. The predicted performance and environmental results of these two advanced open rotor concepts are presented and compared.
\end{abstract}

\section{Introduction}

$\mathrm{T}$ HE oil crisis of the 1970s resulted in a significant shift in aeronautics research efforts in the United States.

Prior to the oil crisis, aeronautics research primarily focused on developing technologies that would allow airplanes to fly higher, faster, and farther. ${ }^{1}$ However, the rise of oil and gasoline prices in the 1970s presented new economic challenges for the airline industry. To address these challenges, NASA initiated a new era of aeronautics research with the primary focus being technologies to reduce aircraft fuel consumption.

The Aircraft Energy Efficiency (ACEE) Program, started in 1973, was the first major program to focus on the fuel consumption objective during this era. In the years since the ACEE project, many other aeronautics research projects have been conducted with the persistent goals of reducing the fuel consumption and the environmental impact of future aircraft. Presently, NASA's Fixed Wing (FW) Project, NASA's Environmentally Responsible Aviation (ERA) Project, and the FAA's Continuous Lower Energy, Emissions and Noise (CLEEN) Program are researching advanced technologies for subsonic transport aircraft that will address these objectives. The FW and ERA Projects have jointly established goals for these objectives as shown in Fig. 1. The goals are generational and the metrics, along with their respective values, have evolved over time and are relative to a set of baseline vehicles. The current metrics address reducing certification noise, oxides of nitrogen (NOx) emissions in the landing/takeoff (LTO) cycle, NOx emissions during cruise, and aircraft fuel/energy consumption. ${ }^{2}$ 


\begin{tabular}{|c|c|c|c|}
\hline \multirow{2}{*}{$\begin{array}{c}\text { TECHNOLOGY } \\
\text { BENEFITS* }\end{array}$} & \multicolumn{3}{|c|}{$\begin{array}{c}\text { TECHNOLOGY GENERATIONS } \\
\text { (Technology Readiness Level = 4-6) }\end{array}$} \\
\cline { 2 - 4 } & $\mathrm{N}+1(2015)$ & $\mathrm{N}+2\left(2020^{* *}\right)$ & $\mathrm{N}+3$ (2025) \\
\hline $\begin{array}{c}\text { Noise } \\
\text { (cum margin rel. to Stage 4) }\end{array}$ & $-32 \mathrm{~dB}$ & $-42 \mathrm{~dB}$ & $-52 \mathrm{~dB}$ \\
\hline $\begin{array}{c}\text { LTO NOx Emissions } \\
\text { (rel. to CAEP 6) }\end{array}$ & $-60 \%$ & $-75 \%$ & $-80 \%$ \\
\hline $\begin{array}{c}\text { Cruise NOx Emissions } \\
\text { (rel. to 2005 best in class) }\end{array}$ & $-55 \%$ & $-70 \%$ & $-80 \%$ \\
\hline $\begin{array}{c}\text { Aircraft Fuel/Energy Consumption } \\
\text { (rel. to 2005 best in class) }\end{array}$ & $-33 \%$ & $-50 \%$ & $-60 \%$ \\
\hline
\end{tabular}

* Projected benefits once technologies are matured and implemented by industry. Benefits vary by vehicle size and mission. $\mathrm{N}+1$ and $\mathrm{N}+3$ values are referenced to a 737-800 with CFM56-7B engines, $\mathrm{N}+2$ values are referenced to a 777-200 with GE90 engines

** ERA's time-phased approach includes advancing "long-pole" technologies to TRL 6 by 2015

$\ddagger \mathrm{CO} 2$ emission benefits dependent on life-cycle CO2e per MJ for fuel and/or energy source used

Figure 1. NASA's Technology Goals for Subsonic Transport Aircraft. ${ }^{2}$

The propulsion system can have a significant impact on reducing the aircraft's fuel consumption and environmental impact. Over the years, numerous technologies have been developed for various engine components that have significantly improved performance in regards to these objectives. As a result, a study conducted in 1999 estimated that aircraft energy efficiency had improved by 3 to 4 percent per year. ${ }^{3}$ While this improvement rate may not be sustainable, there are still numerous promising engine and airframe technologies that can continue to reduce fuel consumption and environmental impacts. Two of the primary engine concepts currently being considered for future subsonic aircraft are the ultra-high bypass (UHB) turbofan, including direct-drive and geared concepts, and the open rotor.

The UHB engine is a natural evolution of the modern turbofan engine. Improvement in component performance, and in some cases the inclusion of a gearbox, can allow higher bypass ratios to be achieved. Higher bypass ratios generally result in higher propulsive efficiency thereby reducing engine fuel consumption and also typically reducing the engine jet noise. The counter-rotating open rotor concept is a considerable departure from traditional turbofans as it uses a set of unducted counter-rotating propellers rather than a ducted fan as the main propulsor, as shown in Fig. 2. The concept was first studied as part of the ACEE's Advanced Turboprop Project in the 1980s. Despite its demonstrated potential to reduce fuel consumption, the open rotor concept never resulted in a commercial product due to falling oil prices, its higher noise levels and the risk associated with developing the new engine. However, recent volatility in oil prices and new design methods that can reduce noise have revived interest in the open rotor concept.

To assess the potential benefits of the UHB and open rotor engine concepts toward meeting the $\mathrm{N}+1$ goals, NASA FW's systems analysis team has undertaken a number of studies to model these engines on an advanced single-aisle transport (ASAT) aircraft. This aircraft would fall into the same class as the Boeing 737 and Airbus A320. Nominally, the ASAT aircraft would be capable of carrying 162 passengers on a 3250 nautical mile flight. The modeling of the UHB concepts for this aircraft has been described in previous publications. ${ }^{4,5}$ Because of its departure from traditional turbofan design, the assessment of the open rotor engine first required a more extensive modeling effort to develop new capabilities. These capabilities have been used for an initial assessment of the open rotor concept (Gen-1). ${ }^{6,7}$ Since this initial assessment was completed, refinements have been made to the model and more advanced open rotor blade designs have been developed and experimentally tested. This paper presents an updated assessment of the Gen-1 open rotor engine. Additionally, a new open rotor engine assessment was completed for a Gen-2 engine which uses data available for these new blade designs. Prior to presenting the results of these two assessments, a summary is provided of the open rotor modeling capabilities and methodology. 


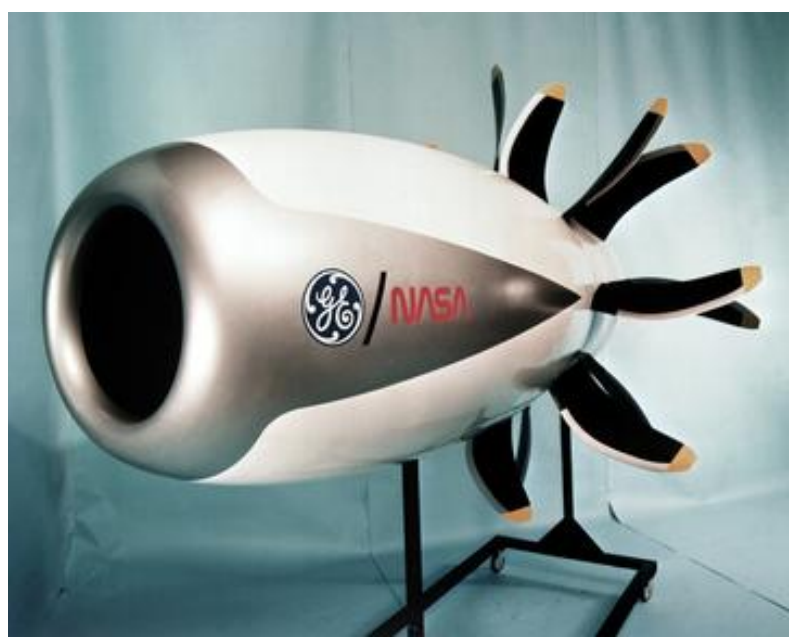

Figure 2. 1980s NASA/GE Unducted Fan Engine.

\section{Summary of Modeling Capabilities and Methodology}

Over the past four years, NASA has worked to develop modeling capabilities and a methodology to enable the impact of open rotor engines to be assessed. These efforts have concentrated primarily on modeling the propulsion system, airframe and the engine/aircraft acoustics. In the development of these modeling capabilities, NASA has worked closely in partnership with General Electric. ${ }^{8}$ This partnership has enabled the use of experimental data in the modeling process and resulted in shared modeling practices, especially in regards to the acoustic assessment. The following sections briefly summarize the relevant modeling capabilities and the overall methodology used in this study.

\section{A. Propulsion Modeling}

One of the major tasks associated with trying to assess the impact of open rotor propulsion systems was developing modeling and design capabilities for these engines. The open rotor engine architecture used in this study was a geared configuration with the component layout shown in Fig. 3. This section provides a brief summary of the modeling and design capabilities that have been developed for open rotor engines with more details available in previous publications. ${ }^{9,10}$

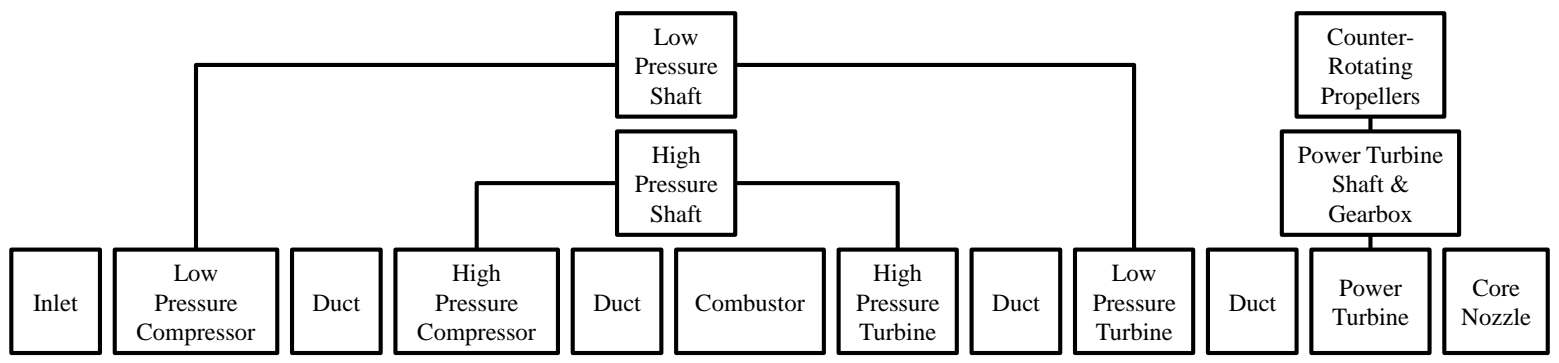

Figure 3. Components of the Open Rotor Engine.

The propulsion system modeling was performed using the Numerical Propulsion System Simulation (NPSS) code ${ }^{11,12,13}$ for thermodynamic cycle analysis and performance. To use NPSS for cycle analysis and performance modeling, a new counter-rotating propeller performance element was added to size the open rotor blades and predict overall thrust and power. This element uses performance maps to determine propeller performance characteristics throughout the flight envelope. Several different counter-rotating per- 
formance maps have been created over the development period of the open rotor cycle analysis capability. First, during the preliminary development phase, a map generation process was established which used data for historic blade designs from the Advanced Turboprop Project in the 1980s. The developed process was then used to create performance maps for a General Electric Gen-1 blade design which was tested at NASA's Glenn Research Center. The new maps were easily integrated into the cycle analysis as demonstrated in the initial Gen-1 study. ${ }^{9}$ For the rest of the engine components, technology assumptions for the current study were based on those used in the NASA advanced turbofan engine design studies described in Refs. 4 and 5. Specific changes to the propulsion cycle model for the revised Gen-1 and Gen-2 studies are described in later sections.

In addition to the cycle analysis, the aeromechanical design and weight of the open rotor engine was modeled using the Weight Analysis of Turbine Engines (WATE) code. ${ }^{14,15,16}$ Enhancements were added to the WATE code to calculate the weight of the counter-rotating propellers. The rotor weight correlation assumes the blades are constructed of polymer composites and is a function of maximum power delivered to the rotor, blade tip-speed, and number of blades. ${ }^{17}$ Furthermore, estimates for emissions of NOx were obtained from an empirical correlation representative of an advanced, low-NOx combustor. Reference 4 provides more details on this empirical NOx correlation, which was developed by NASA combustor technologists during the latter stages of NASA's Ultra-Efficient Engine Technology Program.

\section{B. Airframe Modeling}

The airframe configuration selected for this study was an advanced single-aisle aircraft with the open rotor engines mounted on the rear fuselage as shown in Fig. 4. This configuration uses a pusher engine which is consistent with the recent experiments conducted on open rotor propellers. Furthermore, this configuration was the primary focus of initial open rotor research conducted in the 1980s, providing a wealth of knowledge about open rotor integration.

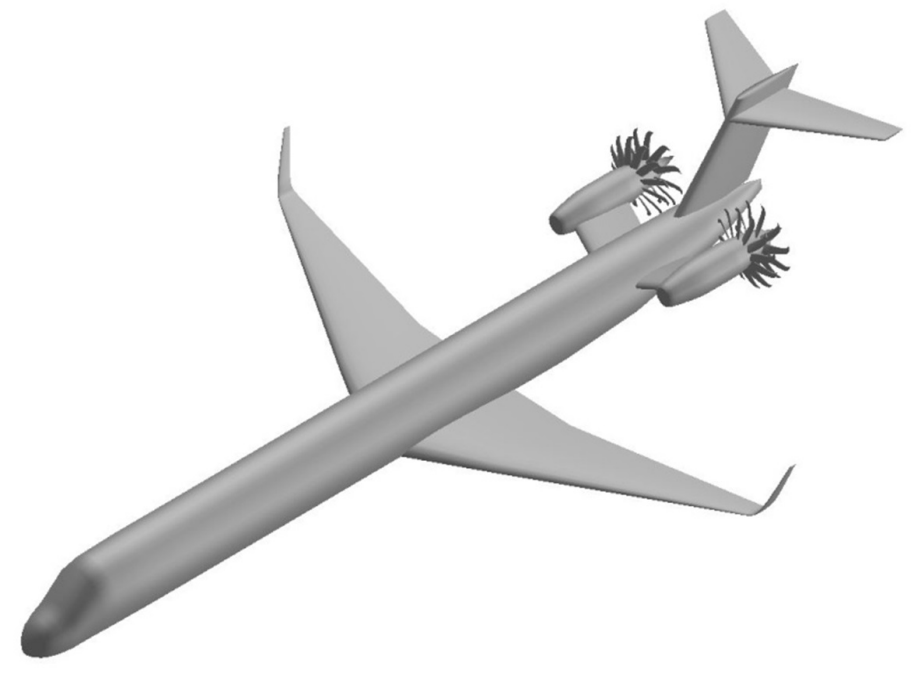

Figure 4. Advanced Single-Aisle Open Rotor Airplane.

In order to develop the airframe model for the open rotor aircraft a series of steps were undertaken. First, a model was developed for an MD-90-30 aircraft. From this baseline model, the airframe was modified through several steps to get to an advanced design representative of a future single aisle aircraft. In the first step, the aerodynamics of the vehicle were improved by accounting for modern airfoils and winglets. Furthermore, the aircraft fuselage was stretched to accommodate 162 passengers and the design mission range was set at $3250 \mathrm{~nm}$. In the second step, advanced vehicle technologies were applied to the airframe. These technologies primarily included the extensive use of composites to reduce wing, fuselage and tail primary structure weight by approximately $15 \%$. Finally, the airframe model was adjusted to integrate open rotor engines. These changes included an increased fuselage weight due to the need for acoustic treatment for cabin noise, additional structure to reduce vibration and address sonic fatigue, and a center-of-gravity 
fuel management system necessitated by heavy aft engines. As a result, the airframe weight increased by approximately $2100 \mathrm{lbs}$ compared to the turbofan version. All of these steps are described in further detail in Ref. 7. The airframe changes described here were modeled using NASA's aircraft sizing and synthesis code FLOPS (Flight Optimization System). ${ }^{18}$

\section{Acoustic Modeling}

Prediction of FAR Part 36 certification noise ${ }^{19}$ for open rotor propulsion is of critical importance in understanding the trades between fuel consumption and noise. Open rotor noise prediction is also an area with significant challenges. A system-level noise prediction method has been developed which uses noise data measured from scale model open rotor test articles. This prediction method is fully described in Ref. 7 and is summarized below.

The system-level noise prediction method is based on acoustic data obtained for advanced counterrotating propellers in the NASA Glenn 9x15 Low-Speed Wind Tunnel. During tests in this wind tunnel, a microphone was traversed alongside the scale model open rotor blades to measure the noise at a number of polar angles. These data were then manipulated to predict the system level noise with the following steps:

1. Initial preparation: spectral density levels of the tare tests were subtracted from each spectrum and converted to sound pressure levels

2. Conversion to static conditions: sound pressure levels were corrected for convection effects to static conditions

3. Conversion to flight conditions: sound pressure levels were corrected to realistic takeoff and approach flight conditions

4. Conversion to full scale: sound pressure levels were then corrected from model scale to full scale

5. Conversion to 1/3rd octave band spectra: sound pressure levels were converted to the 24 discrete sound pressure levels of the $1 / 3$ rd octave band center frequency spectrum used as the basis for FAA and ICAO noise certification

After manipulating the data with these steps to predict full scale 1/3rd octave band spectra for the open rotor, propulsion core, tailpipe jet, and airframe noise sources were added and the Aircraft Noise Prediction Program (ANOPP) was used to fly the aircraft through its takeoff and landing trajectories and to calculate the noise at each of the FAR Part 36 certification points.

\section{Gen-1 Open Rotor Study Improvements and Results}

Following the original publication of the Gen-1 open rotor study, ${ }^{6,7}$ a number of improvements were made to the engine, airframe and acoustics models. These improvements were made to incorporate lessons learned from an ongoing NASA UHB study and improve the model fidelity. These improvements along with the modeling capabilities and methodology described in the previous section have been used to analyze an advanced open rotor propulsion system on an Advanced Single-Aisle Transport (ASAT) aircraft. The following sections describe in detail the improvements made to the models and present results from the updated model.

\section{A. Propulsion System Model Improvements}

The propulsion system cycle and mechanical models were updated following the initial publication. For the cycle analysis, the only change was to the turbine cooling assumptions. In the initial model, it was envisioned that only the high and low pressure turbines would require cooling. However, further review of the model identified that the high and low pressure turbine cooling projections needed to be refined and additional cooling was required in the power turbine. Therefore, the cooling assumptions of all three turbine components were reassessed to provide more realistic cooling projections. However, these modifications resulted in only minor changes in engine performance characteristics as shown in Table 1. In addition to the cycle analysis results, the emissions model for the revised engine predicted a certification LTO NOx value of $9.48 \mathrm{~g} \mathrm{NOx} / \mathrm{kN}$ which is $83.2 \%$ below the CAEP/ 6 rule. ${ }^{20,21}$ 
Table 1. Comparison of Initial and Revised Gen-1 Open Rotor Cycle Models.

\begin{tabular}{|c|c|c|}
\hline & Gen-1 Initial & Gen-1 Revised \\
\hline \multicolumn{3}{|l|}{ Thrust, lbf } \\
\hline Sea Level Static, $\mathrm{M}=0.0,0 \mathrm{ft}, \mathrm{ISA}+27^{\circ} \mathrm{F}$ & 27,260 & 27,275 \\
\hline Rolling Takeoff, $\mathrm{M}=0.25,0 \mathrm{ft}, \mathrm{ISA}+27^{\circ} \mathrm{F}$ & 19,000 & 19,000 \\
\hline Top-of-Climb, M=0.78, $35,000 \mathrm{ft}$ & 5,000 & 5,000 \\
\hline \multicolumn{3}{|l|}{ TSFC, lbm/hr $/ \mathrm{lbf}$} \\
\hline Sea Level Static, $\mathrm{M}=0.0,0 \mathrm{ft}, \mathrm{ISA}+27^{\circ} \mathrm{F}$ & 0.158 & 0.158 \\
\hline Rolling Takeoff, $\mathrm{M}=0.25,0 \mathrm{ft}, \mathrm{ISA}+27^{\circ} \mathrm{F}$ & 0.229 & 0.229 \\
\hline Top-of-Climb, M=0.78, 35,000 ft & 0.428 & 0.429 \\
\hline \multicolumn{3}{|l|}{ Overall Pressure Ratio } \\
\hline Sea Level Static, $\mathrm{M}=0.0,0 \mathrm{ft}, \mathrm{ISA}+27^{\circ} \mathrm{F}$ & 29.43 & 29.39 \\
\hline Rolling Takeoff, $\mathrm{M}=0.25,0 \mathrm{ft}, \mathrm{ISA}+27^{\circ} \mathrm{F}$ & 28.49 & 28.43 \\
\hline Top-of-Climb, M=0.78, 35,000 ft & 42.00 & 42.00 \\
\hline \multicolumn{3}{|l|}{ Combustor Exit Temperature, $\mathbf{R}$} \\
\hline Sea Level Static, $\mathrm{M}=0.0,0 \mathrm{ft}, \mathrm{ISA}+27^{\circ} \mathrm{F}$ & 3,460 & 3,460 \\
\hline Rolling Takeoff, $\mathrm{M}=0.25,0 \mathrm{ft}, \mathrm{ISA}+27^{\circ} \mathrm{F}$ & 3,460 & 3,460 \\
\hline Top-of-Climb, M=0.78, 35,000 ft & 3,284 & 3,286 \\
\hline
\end{tabular}

In addition to updating the engine cycle analysis, the engine mechanical design and weight estimates were also revised. The primary change was the use of a more conservative gear-weight correlation. Following the initial open rotor study it was noted that a larger thermal management system might be needed for the open rotor due to higher heat loads generated. Therefore, a new NASA developed gearbox weight correlation which better captures the increased thermal management system weight was used in the current analysis. The current gear correlation is a function of maximum delivered output power and gear ratio, and is based on actual gearbox weight data from over fifty rotorcraft, tiltrotor, and turboprop aircraft. The results for the previous and current Gen-1 mechanical and weight analysis are provided in Table 2. The new gearbox weight correlation added approximately 100 pounds to the overall engine weight. In addition, an oversight was discovered in the weight calculation of the HPC. Correction of this error resulted in a weight increase of about 45 pounds for the gas generator. A solid model showing the internal turbomachinery and open rotor blades for the revised Gen-1 engine was created using NASA's Vehicle Sketch Pad (VSP) as shown in Fig. 5.

\section{B. Airframe Model Improvements}

In addition to the modeling improvements made to the open rotor propulsion system, improvements were also made to the vehicle sizing analysis. The primary enhancement was a change in the aircraft sizing approach from a single point mission sizing to a multi-point sizing. Because the advanced aircraft in these type of studies are more fuel efficient than the baseline aircraft, their range is more sensitive to changes in payload weight. As a result, even when the range capability of the baseline vehicle is matched for the nominal design mission (32,400 $\mathrm{lb}$ payload and $3250 \mathrm{~nm}$ range in this case), there can be a significant loss in range capability of the advanced aircraft at higher payloads. To ensure equivalent capability for high payload missions, the advanced vehicles were sized such that the range capability would be at least that of the baseline vehicle at both the maximum payload and the design payload.

Minor changes were also made in the tail sizing methodology, propulsion installation weight model, and operating item weight model. The results of the updated vehicle sizing process incorporating the updated engine performance and weight are shown in Table 3 . The changes in the airframe modeling and sizing approach resulted in a 10,000 pound increase in the maximum takeoff weight of the open rotor airplane. This increase is due to the higher fuel load needed to match baseline range capability at the maximum payload weight, as well as increases from the compounding effects of a higher maximum weight (larger wing area, larger engine, heavier structure). This increase in weight increased the required wing area and thrust 
Table 2. Comparison of Initial and Revised Gen-1 Open Rotor Mechanical Models.

\begin{tabular}{|l|r|r|}
\hline & Gen-1 Initial & Gen-1 Revised \\
\hline Total Engine Pod Weight, lbm & 9,220 & 9,375 \\
\hline Counter-Rotating Propeller Weight, lbm & 3,240 & 3,240 \\
\hline Gearbox Weight, lbm & 1,030 & 1,140 \\
\hline Gas Generator, Turbomachinery Weight, lbm & 4,950 & 4,995 \\
\hline Maximum Propeller Diameter, ft & 13.8 & 13.8 \\
\hline Nacelle Diameter, ft & 5.6 & 5.6 \\
\hline Overall Length, ft & 23.2 & 23.2 \\
\hline Low Pressure Compressor Stages & 4 & 4 \\
\hline High Pressure Compressor Stages & 7 & 7 \\
\hline High Pressure Turbine Stages & 1 & 1 \\
\hline Low Pressure Turbine Stages & 1 & 1 \\
\hline Power Turbine Stages & 3 & 3 \\
\hline Gear Ratio & 6.0 & 6.0 \\
\hline
\end{tabular}

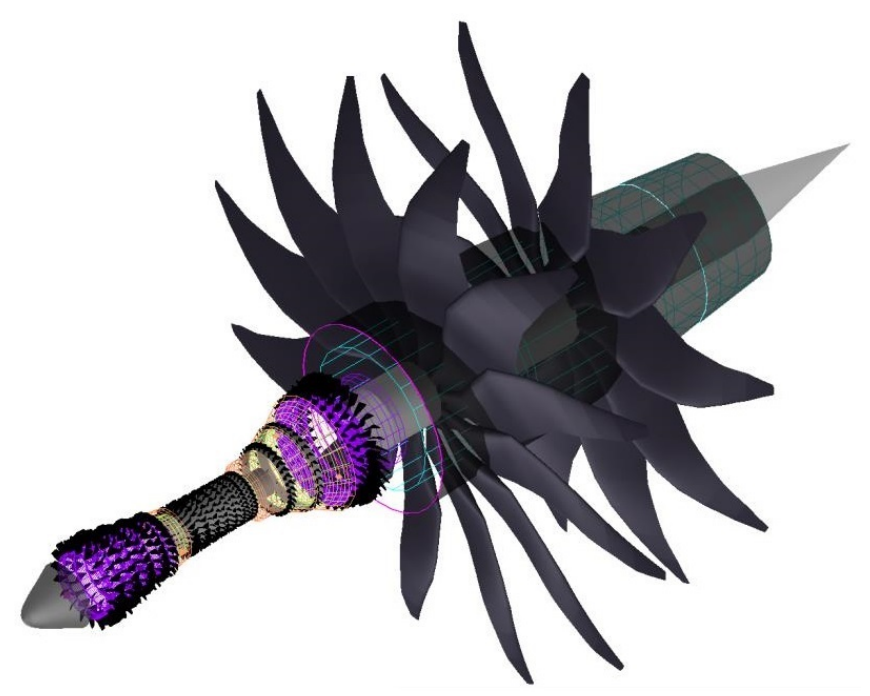

Figure 5. VSP Model of the Revised Gen-1 Open Rotor Engine.

by about $5.5 \%$. For the design mission, the total fuel burn increased by about $1.6 \%$ for the revised airplane. However, the total mission NOx decreased slightly because of slightly higher cruise altitudes for the revised Gen-1 airplane . A comparison of the initial and revised Gen-1 design mission results are shown in Fig. 6.

\section{Acoustic Model Improvements}

The acoustic analysis now incorporates a notable change following the original publication. During the experimental testing of the open rotor blades, strain gauges were affixed to the blades to measure structural strain in real time for safety. Near the end of the overall testing program, the strain gauges were identified as a possible noise source. Therefore, tests were run without the strain gauges and resulted in lower noise levels. From these tests, a system correction was developed and implemented which accounted for the noise produced by the test article instrumentation.

In addition, the revised engine and airframe sizing analyses resulted in small differences in the propulsion system size and in the takeoff and approach trajectory characteristics. These changes resulted in revised 
Table 3. Comparison of Initial and Revised Gen-1 Open Rotor Vehicle Models.

\begin{tabular}{|c|c|c|}
\hline & Gen-1 Initial & Gen-1 Revised \\
\hline \multicolumn{3}{|l|}{ Sizing Results } \\
\hline Wing Area, $\mathrm{ft}^{2}$ & 1,250 & 1,320 \\
\hline Thrust (Sea Level Static), lbf & 26,900 & 28,400 \\
\hline Maximum Takeoff Weight (MTOW), lbm & 151,300 & 161,500 \\
\hline Wing Loading (MTOW), lbm/ $\mathrm{ft}^{2}$ & 121 & 122 \\
\hline Thrust-to-Weight Ratio (MTOW) & 0.356 & 0.352 \\
\hline Landing Field Length, ft & 6,010 & 6,180 \\
\hline Takeoff Field Length, ft & 6,260 & 6,430 \\
\hline LTO NOx, lbm/cycle & 6.41 & 6.22 \\
\hline \multicolumn{3}{|l|}{ Design Mission Results } \\
\hline Operational Empty Weight, lbm & 87,800 & 91,300 \\
\hline Mission Fuel, lbm & 31,100 & 31,600 \\
\hline Payload Weight, lbm & 32,400 & 32,400 \\
\hline Ramp Weight, lbm & 151,300 & 155,300 \\
\hline Block Fuel, lbm & 26,700 & 27,150 \\
\hline Block NOx, lbm & 216 & 210 \\
\hline
\end{tabular}

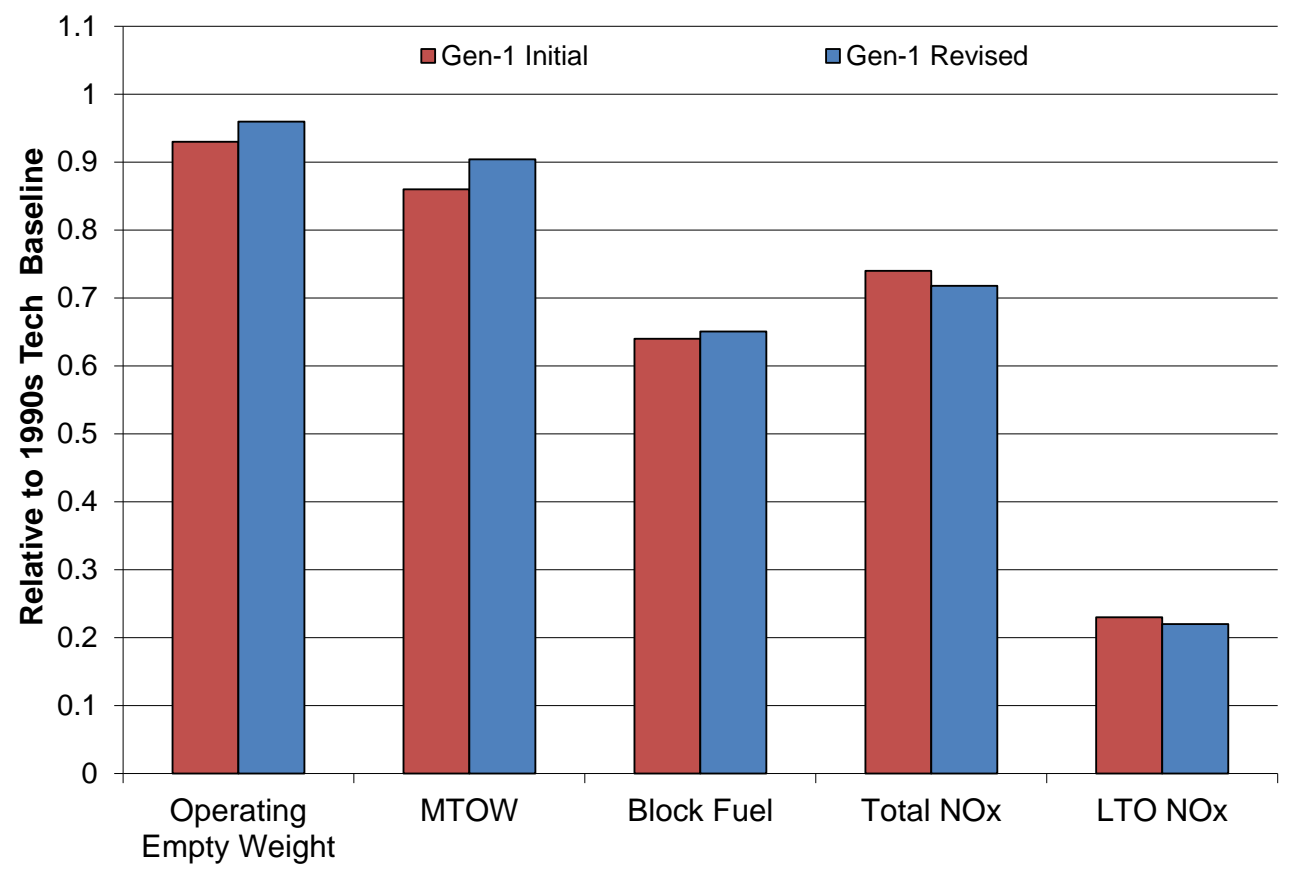

Figure 6. Comparison of Initial and Revised Gen-1 Open Rotor Vehicle Models for the Design Mission.

acoustic results for the Gen-1 open rotor study as shown in Table 4. The differences in the prediction resulted in almost no change to the estimated overall system noise. However, because of the changes in the vehicle weight, the margin relative to the Chapter 3 and Chapter 4 rules improved. Therefore, the revised Gen-1 study indicates about a $1 \mathrm{EPNdB}$ improvement in the cumulative margin to Chapter 4 than previously reported. 
Table 4. Comparison of Initial and Revised Gen-1 Open Rotor Acoustic Models.

\begin{tabular}{|l|r|r|r|r|}
\hline & Lateral & Flyover & Approach & Cumulative \\
\hline Gen-1 Initial \\
\hline Overall System, EPNdB & 92.0 & 83.8 & 89.5 & 265.2 \\
\hline Chapter 3 Rule, EPNdB & 96.5 & 91.0 & 100.3 & 287.8 \\
\hline Chapter 3 Margin, EPNdB & 4.5 & 7.3 & 10.7 & 22.6 \\
\hline Chapter 4 Margin, EPNdB & - & - & - & 12.6 \\
\hline Gen-1 Revised & 91.7 & 84.2 & 89.2 & 265.0 \\
\hline Overall System, EPNdB & 96.7 & 91.4 & 100.5 & 288.6 \\
\hline Chapter 3 Rule, EPNdB & 5.0 & 7.2 & 11.3 & 23.6 \\
\hline Chapter 3 Margin, EPNdB & - & - & - & 13.6 \\
\hline Chapter 4 Margin, EPNdB &
\end{tabular}

\section{Gen-2 Open Rotor Study}

Following the revision to the Gen-1 study, a second study was conducted to assess the impact of new Gen2 open rotor blade designs. The revised Gen-1 engine, airframe and acoustic models were used as a starting point for model development. The Gen-2 engine and airplane were sized to meet the same performance and mission requirements as the Gen-1 study. The following sections describe the specific changes made to the propulsion, vehicle and acoustic models as well as the results from each.

\section{A. Propulsion System Model}

The propulsion system model was updated to capture the performance of the Gen-2 blade set. To capture the performance, new maps were created based on experimental data obtained from a General Electric Gen-2 rotor design that was tested at the NASA Glenn 8x6-ft Supersonic Wind Tunnel and 9x15-ft Low-Speed Wind Tunnel complex with funding from the FAA's CLEEN Program. In addition to changing the performance maps, other design variables such as the tip speed, torque ratio and disk loading were updated. A comparison of the engine cycle data from the Gen- 1 and Gen-2 models is provided in Table 5 . The Gen-2 engine model was sized for the same rolling takeoff and top-of-climb thrust requirements as the Gen-1 engine. However, the Gen-2 engine provides about 500 pounds of additional thrust at sea-level static. For the engine fuel consumption, the cycle models predict slightly lower TSFC for the Gen-1 engine at both sea-level static and rolling takeoff operating conditions. At the top-of-climb operating point however, the Gen-2 engine model predicts a lower TSFC. For the rest of the engine cycle data, similar values are predicted for both engines. Because of the increased fuel consumption at takeoff, the certification LTO NOx of the Gen-2 engine was higher at $12.15 \mathrm{~g} \mathrm{NOx} / \mathrm{kN}$ which is $79.4 \%$ below the $\mathrm{CAEP} / 6$ rule. ${ }^{20,21}$

The weight and mechanical model of the Gen-2 engine predicts some differences when compared to the revised Gen-1 study as shown in Table 6. The counter-rotating propellers for the Gen-2 engine are about 3 inches smaller in diameter. This decrease results in a reduced propeller weight. This reduced propeller weight is offset by an increase in the gearbox weight. The gearbox weight increased due to an increase in the gear ratio which was necessitated by the lower propeller tip speed. Other than those changes, the mechanical design and weight estimate of the Gen-2 engine was similar to the revised Gen-1 results.

\section{B. Airframe Model}

Next, the Gen-2 open rotor engine model was incorporated into the vehicle sizing and mission analysis. The same vehicle assumptions and design missions were considered as for the Gen-1 study. Table 7 gives the results for both the revised Gen-1 and Gen-2 vehicle analyses. The two airplanes are generally similar, with the Gen-2 airplane requiring about 500 pounds less fuel $(1.8 \%)$ to fly the design mission. The lower fuel burn of the Gen-2 airplane is primarily due to the lower engine TSFC during the cruise portion of the mission. A comparison of the performance of the revised Gen-1 and Gen-2 airplanes to a 1990s technology baseline airplane is shown in Fig. 7. 
Table 5. Comparison of Revised Gen-1 and Gen-2 Open Rotor Cycle Models.

\begin{tabular}{|l|r|r|}
\hline & Gen-1 Revised & Gen-2 \\
\hline Thrust, lbf & 27,275 & 27,810 \\
\hline Sea Level Static, $\mathrm{M}=0.0,0 \mathrm{ft}, \mathrm{ISA}+27^{\circ} \mathrm{F}$ & 19,000 & 19,000 \\
\hline Rolling Takeoff, $\mathrm{M}=0.25,0 \mathrm{ft}, \mathrm{ISA}+27^{\circ} \mathrm{F}$ & 5,000 & 5,000 \\
\hline Top-of-Climb, M=0.78, 35,000 ft & 0.158 & 0.161 \\
\hline TSFC, lbm/hr $/ \mathrm{lbf}$ & 0.229 & 0.238 \\
\hline Sea Level Static, $\mathrm{M}=0.0,0 \mathrm{ft}, \mathrm{ISA}+27^{\circ} \mathrm{F}$ & 0.429 & 0.415 \\
\hline Rolling Takeoff, M=0.25, 0 ft, ISA $+27^{\circ} \mathrm{F}$ & 29.39 & 31.01 \\
\hline Top-of-Climb, M=0.78, 35,000 ft & 28.43 & 30.07 \\
\hline Overall Pressure Ratio & 42.00 & 42.00 \\
\hline Sea Level Static, M=0.0, $0 \mathrm{ft}, \mathrm{ISA}+27^{\circ} \mathrm{F}$ & 3,460 & 3,460 \\
\hline Rolling Takeoff, $\mathrm{M}=0.25,0 \mathrm{ft}, \mathrm{ISA}+27^{\circ} \mathrm{F}$ & 3,460 & 3,460 \\
\hline Top-of-Climb, M=0.78, 35,000 ft & 3,286 & 3,225 \\
\hline Combustor Exit Temperature, $\mathbf{R}$ &
\end{tabular}

Table 6. Comparison of Revised Gen-1 and Gen-2 Open Rotor Mechanical Models.

\begin{tabular}{|l|r|r|}
\hline & Gen-1 Revised & Gen-2 \\
\hline Total Engine Pod Weight, lbm & 9,375 & 9,365 \\
\hline Counter-Rotating Propeller Weight, lbm & 3,240 & 3,020 \\
\hline Gearbox Weight, lbm & 1,140 & 1,350 \\
\hline Gas Generator, Turbomachinery Weight, lbm & 4,995 & 4,995 \\
\hline Maximum Propeller Diameter, ft & 13.8 & 13.5 \\
\hline Nacelle Diameter, ft & 5.6 & 5.6 \\
\hline Overall Length, ft & 23.2 & 23.2 \\
\hline Low Pressure Compressor Stages & 4 & 4 \\
\hline High Pressure Compressor Stages & 7 & 7 \\
\hline High Pressure Turbine Stages & 1 & 1 \\
\hline Low Pressure Turbine Stages & 1 & 1 \\
\hline Power Turbine Stages & 3 & 3 \\
\hline Gear Ratio & 6.0 & 6.7 \\
\hline
\end{tabular}

\section{Acoustic Model}

Finally, an acoustic model was developed for the Gen-2 study. The procedure described previously was again used with the basis being acoustic measurements from the NASA 9x15 wind tunnel. In addition to the analysis process previously described, several additional corrections were applied. First, the model was again adjusted to remove the effects of instrumentation that were discovered during the wind tunnel experiments. Second, the Gen-2 blades used as the starting point for these calculations were designed to accommodate several company-proprietary low noise features that are left undescribed in this forum. However, not all of these noise reduction features were included in their design. Other complementary low noise features were tested on the Gen-1 blades and it is believed that they could be included in a final open rotor design with 
Table 7. Comparison of Revised Gen-1 and Gen-2 Open Rotor Vehicle Models.

\begin{tabular}{|c|c|c|}
\hline & Gen-1 Revised & Gen-2 \\
\hline \multicolumn{3}{|l|}{ Sizing Results } \\
\hline Wing Area, $\mathrm{ft}^{2}$ & 1,320 & 1,320 \\
\hline Thrust (Sea Level Static), lbf & 28,400 & 28,900 \\
\hline Maximum Takeoff Weight (MTOW), lbm & 161,500 & 161,100 \\
\hline Wing Loading (MTOW), lbm $/ \mathrm{ft}^{2}$ & 122 & 122 \\
\hline Thrust-to-Weight Ratio (MTOW) & 0.352 & 0.358 \\
\hline Landing Field Length, ft & 6,180 & 6,170 \\
\hline Takeoff Field Length, ft & 6,430 & 6,250 \\
\hline LTO NOx, lbm/cycle & 6.22 & 7.23 \\
\hline \multicolumn{3}{|l|}{ Design Mission Results } \\
\hline Operational Empty Weight, lbm & 91,300 & 91,250 \\
\hline Mission Fuel, lbm & 31,600 & 31,100 \\
\hline Payload Weight, lbm & 32,400 & 32,400 \\
\hline Ramp Weight, lbm & 155,300 & 154,800 \\
\hline Block Fuel, lbm & 27,150 & 26,700 \\
\hline Block NOx, lbm & 210 & 197 \\
\hline
\end{tabular}

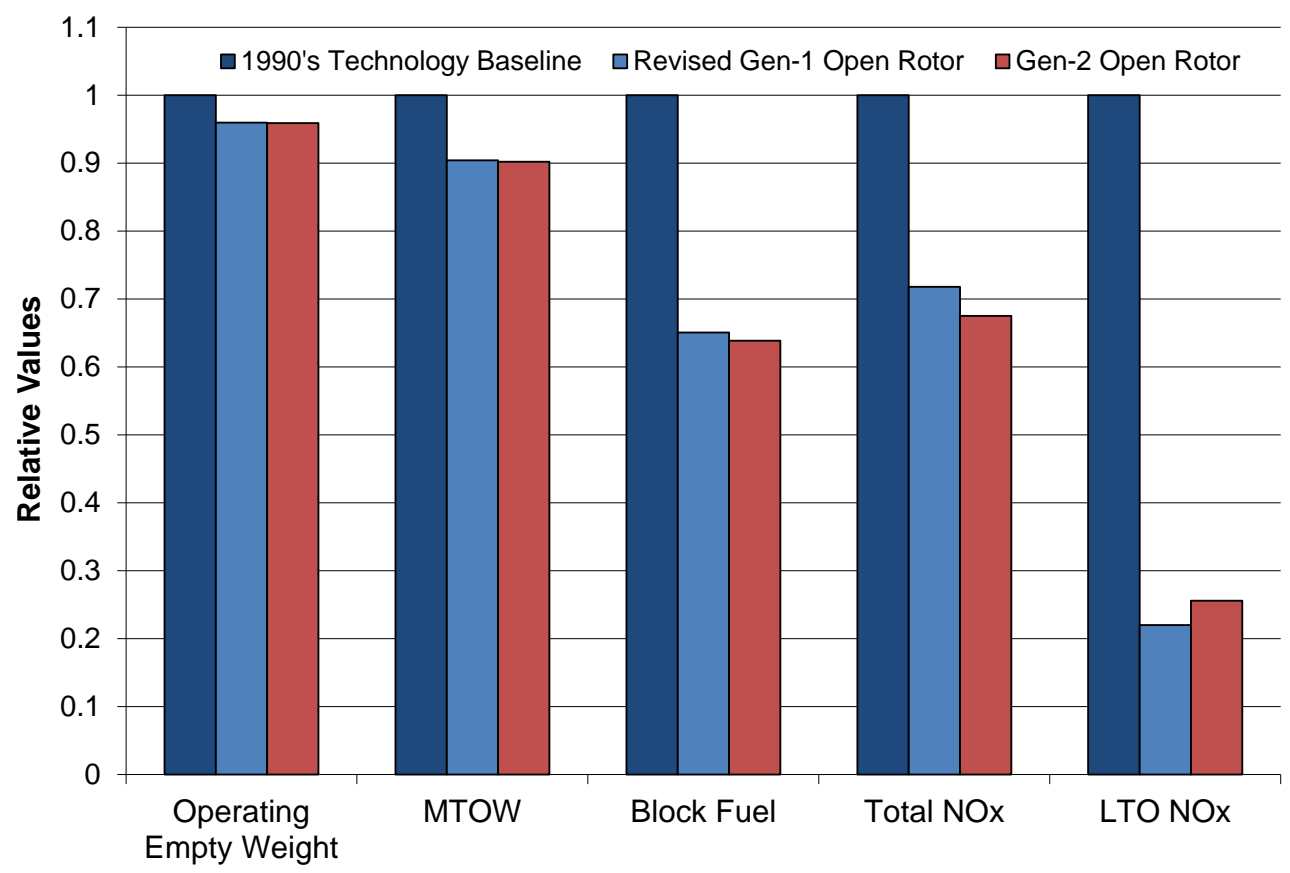

Figure 7. Comparison of Revised Gen-1 and Gen-2 Open Rotor Vehicle Models for the Design Mission.

no impact on performance. Therefore, an additional correction was applied to the measured Gen-2 blade noise characteristics to account for the application of selected Gen-1 blade low noise features. Applying these additional corrections to the acoustic modeling process resulted in the certification noise values given in Table 8. The acoustic model predicts a Chapter 4 cumulative margin of $16.8 \mathrm{EPNdB}$. This is about a 3 EPNdB improvement over the Gen-1 airplane. 
Table 8. Gen-2 Open Rotor Acoustic Model Results.

\begin{tabular}{|l|r|r|r|r|}
\hline & Lateral & Flyover & Approach & Cumulative \\
\hline Overall System, EPNdB & 90.1 & 82.2 & 89.5 & 261.8 \\
\hline Chapter 3 Rule, EPNdB & 96.7 & 91.4 & 100.5 & 288.6 \\
\hline Chapter 3 Margin, EPNdB & 6.6 & 9.2 & 11.0 & 26.8 \\
\hline Chapter 4 Margin, EPNdB & - & - & - & 16.8 \\
\hline
\end{tabular}

\section{Conclusion}

Over the last few years, NASA has undertaken a number of studies to assess the impact of advanced propulsion systems on future aircraft. These studies have primarily focused on evaluating the potential reduction of mission fuel consumption, emissions and noise. This paper presented two studies on advanced open rotor propulsion systems and assessed their potential impact on each of these objectives. These studies examined two different generations of open rotor blade designs which were both tested in NASA Glenn Research Center wind tunnels.

In the first study, the NASA systems analysis team updated the initial assessment of the Gen-1 open rotor and detailed revisions to the propulsion, vehicle and acoustic analyses. These updates resulted in only minor changes to the propulsion system model. However, more significant changes were made to the vehicle and acoustic analyses as a result of improved modeling methods and assumptions. Overall, the changes in the Gen-1 study resulted in a heavier airplane that required slightly more fuel to complete its design mission. However, improvements in the acoustic modeling resulted in an increased cumulative margin to Chapter 4 noise rules.

For the Gen-2 study, a modified blade design was used in the propulsion and acoustic analyses. Using the Gen-2 blade design, the propulsion model predicted a lower TSFC at cruise as a result of slightly higher propeller efficiency. The lower Gen-2 engine TSFC had the effect of reducing the fuel required to complete the design mission relative to the Gen-1 study. In addition, the acoustic assessment of the vehicle was impacted by the use of the Gen-2 blade designs which incorporated further lower noise features. As a result, the predicted margin to Chapter 4 regulations increased by about 3 EPNdB cumulative compared to the Gen-1 design.

Both the Gen-1 and Gen-2 studies presented here demonstrate that the open rotor engine concept has the potential to help meet NASA's subsonic transport technology goals. Primarily, these open rotor studies show that low fuel consumption and emissions are achievable with this engine concept. Furthermore, the acoustic assessments show that an open rotor engine on a tube and wing aircraft has a significant margin to current noise regulations. These results indicate that the open rotor engine is a promising concept which merits consideration for further investigations as part of a broader propulsion technology portfolio.

\section{References}

\footnotetext{
${ }^{1}$ Bowles, M. D., "The Apollo of Aeronautics, NASAs Aircraft Energy Efficiency Program," NASA SP-2009-574, 2010.

${ }^{2}$ Del Rosario, R., "NASA Subsonic Fixed Wing Project Overview," 2012 NASA Fundamental Aeronautics Program Technical Conference, Renaissance Cleveland Hotel, Cleveland, Ohio.

${ }^{3}$ Mastny, L., "World Air Traffic Soaring," Vital signs 1999: The Environmental Trends that are Shaping Our Future, edited by L. R. Brown, M. Renner, and L. Starke, Norton, New York, 1999, p. 86.

${ }^{4}$ Guynn, M. D., Berton, J. J., Fisher, K. L., Haller, W. J., Tong, M., and Thurman, D. R., "Engine Concept Study for an Advanced Single-Aisle Transport," NASA TM-2009-215784, 2009.

${ }^{5}$ Guynn, M. D., Berton, J. J., Fisher, K. L., Haller, W. J., Tong, M. T., and Thurman, D. R., "Refined Exploration of Turbofan Design Options for an Advanced Single-Aisle Transport," NASA TM-2011-216883, 2011.

${ }^{6}$ Guynn, M. D., Berton, J. J., Hendricks, E. S., Tong, M. T., Haller, W. J., and Thurman, D. R., "Initial Assessment of Open Rotor Propulsion Applied to an Advanced Single-Aisle Aircraft," AIAA 2011-7058, 2011.

${ }^{7}$ Guynn, M. D., Berton, J. J., Haller, W. J., Hendricks, E. S., and Tong, M. T., "Performance and Environmental Assessment of an Advanced Aircraft with Open Rotor Propulsion," NASA TM-2012-217772, 2012.

8 "GE and NASA Partner on Open Rotor Engine Testing," URL: http://www.nasa.gov/offices/oce/appel/askacademy/issues/volume2/AA_2-3_F_ge_rotor.html [cited 5/21/2013].
} 
${ }^{9}$ Hendricks, E. S., "Development of an Open Rotor Cycle Model in NPSS Using a Multi-Design Point Approach," ASME GT2011-46694, 2011.

${ }^{10}$ Hendricks, E. S. and Tong, M. T., "Performance and Weight Estimates for an Advanced Open Rotor Engine," AIAA2012-3911, NASA TM-2012-217710, 2012.

${ }^{11}$ Claus, R., Evans, A., Lylte, J., and Nichols, L., "Numerical Propulsion System Simulation," Computing Systems in Engineering, Vol. 2, No. 4, 1991, pp. 357-364.

12 NPSS User Guide Software Release: NPSS 1.6.5.

${ }^{13}$ NPSS Reference Sheets Software Release: NPSS 1.6.5.

${ }^{14}$ Onat, E. and Klees, G., "A Method to Estimate Weight and Dimensions of Large and Small Gas Turbine Engines," NASA CR-159481, 1979.

${ }^{15}$ Tong, M. T., Halliwell, I., and Ghosn, L. J., "A Computer Code for Gas Turbine Engine Weight and Disk Life Estimation," Journal of Engineering for Gas Turbines and Power, Vol. 126, No. 2, 2004, pp. 265-270.

${ }^{16}$ Tong, M. T. and Naylor, B. A., "An Object-Oriented Computer Code for Aircraft Engine Weight Estimation," ASME GT2008-50062, 2008.

${ }^{17}$ Weisbrich, A. L., Godston, J., and Bradley, E., "Technology and Benefits of High Speed Aircraft Counter Rotation Propellers," NASA CR168258, 1982.

${ }^{18}$ McCullers, L., "Aircraft Configuration Optimization Including Optimized Flight Profiles," Proceedings of the Symposium on Recent Experiences in Multidisciplinary Analysis and Optimization, NASA CP-2327, 1984.

19 "Noise Standards: Aircraft Type and Airworthiness Certification," U.S. Code of Federal Regulations, Title 14, Chapter I, Part 36 .

20 "International Standards and Recommended Practices - Environmental Protection, Annex 16 to the Convention on International Civil Aviation, Vol. II: Aircraft Engine Emissions, 2nd ed." International Civil Aviation Organization (ICAO), Montreal, Canada, July 1993.

21 "Fuel Venting and Exhaust Emission Requirements for Turbine EnginePowered Airplanes," U.S. Code of Federal Regulations, Title 14, Chap. I, Part 34. 


\begin{tabular}{|c|c|c|}
\hline \multicolumn{2}{|c|}{ REPORT DOCUMENTATION PAGE } & $\begin{array}{l}\text { Form Approved } \\
\text { OMB No. 0704-0188 }\end{array}$ \\
\hline \multicolumn{3}{|c|}{$\begin{array}{l}\text { The public reporting burden for this collection of information is estimated to average } 1 \text { hour per response, including the time for reviewing instructions, searching existing data sources, gathering and maintaining the } \\
\text { data needed, and completing and reviewing the collection of information. Send comments regarding this burden estimate or any other aspect of this collection of information, including suggestions for reducing this } \\
\text { burden, to Department of Defense, Washington Headquarters Services, Directorate for Information Operations and Reports (0704-0188), } 1215 \text { Jefferson Davis Highway, Suite } 1204 \text {, Allington, VA } 22222-24302 \text {. } \\
\text { Respondents should be aware that notwithstanding any other provision of law, no person shall be subject to any penalty for failing to comply with a collection of information if it does not display a currently valid OMB } \\
\text { control number. } \\
\text { PLEASE DO NOT RETURN YOUR FORM TO THE ABOVE ADDRESS. }\end{array}$} \\
\hline $\begin{array}{l}\text { 1. REPORT DATE (DD-MM-YYYY) } \\
01-08-2013\end{array}$ & $\begin{array}{l}\text { 2. REPORT TYPE } \\
\text { Technical Memorandum }\end{array}$ & 3. DATES COVERED (From - To) \\
\hline \multirow{3}{*}{\multicolumn{2}{|c|}{$\begin{array}{l}\text { 4. TITLE AND SUBTITLE } \\
\text { Updated Assessment of an Open Rotor Airplane Using an Advanced Blade Design }\end{array}$}} & 5a. CONTRACT NUMBER \\
\hline & & 5b. GRANT NUMBER \\
\hline & & 5c. PROGRAM ELEMENT NUMBER \\
\hline \multirow{3}{*}{\multicolumn{2}{|c|}{$\begin{array}{l}\text { 6. AUTHOR(S) } \\
\text { Hendricks, Eric, S.; Berton, Jeffrey, J.; Haller, William, J.; Tong, Michael, T.; Guynn, Mark, } \\
\text { D. }\end{array}$}} & 5d. PROJECT NUMBER \\
\hline & & 5e. TASK NUMBER \\
\hline & & $\begin{array}{l}\text { 5f. WORK UNIT NUMBER } \\
\text { WBS 473452.02.03.02.01 }\end{array}$ \\
\hline \multicolumn{2}{|c|}{$\begin{array}{l}\text { 7. PERFORMING ORGANIZATION NAME(S) AND ADDRESS(ES) } \\
\text { National Aeronautics and Space Administration } \\
\text { John H. Glenn Research Center at Lewis Field } \\
\text { Cleveland, Ohio 44135-3191 }\end{array}$} & $\begin{array}{l}\text { 8. PERFORMING ORGANIZATION } \\
\text { REPORT NUMBER } \\
\text { E-18749 }\end{array}$ \\
\hline \multirow{2}{*}{\multicolumn{2}{|c|}{$\begin{array}{l}\text { 9. SPONSORING/MONITORING AGENCY NAME(S) AND ADDRESS(ES) } \\
\text { National Aeronautics and Space Administration } \\
\text { Washington, DC 20546-0001 }\end{array}$}} & $\begin{array}{l}\text { 10. SPONSORING/MONITOR'S } \\
\text { ACRONYM(S) } \\
\text { NASA }\end{array}$ \\
\hline & & $\begin{array}{l}\text { 11. SPONSORING/MONITORING } \\
\text { REPORT NUMBER } \\
\text { NASA/TM-2013-218074 }\end{array}$ \\
\hline \multicolumn{3}{|c|}{$\begin{array}{l}\text { 12. DISTRIBUTIONIAVAILABILITY STATEMENT } \\
\text { Unclassified-Unlimited } \\
\text { Subject Categories: } 05 \text { and } 07 \\
\text { Available electronically at http://www.sti.nasa.gov } \\
\text { This publication is available from the NASA Center for AeroSpace Information, 443-757-5802 }\end{array}$} \\
\hline
\end{tabular}

\section{SUPPLEMENTARY NOTES}

\section{ABSTRACT}

Application of open rotor propulsion systems (historically referred to as “advanced turboprops” or “propfans”) to subsonic transport aircraft received significant attention and research in the 1970s and 1980s when fuel efficiency was the driving focus of aeronautical research.

Recent volatility in fuel prices and concern for aviation's environmental impact have renewed interest in open rotor propulsion, and revived research by NASA and a number of engine manufacturers. Over the last few years, NASA has revived and developed analysis capabilities to assess aircraft designs with open rotor propulsion systems. These efforts have been described in several previous papers along with initial results from applying these capabilities. The initial results indicated that open rotor engines have the potential to provide large reductions in fuel consumption and emissions. Initial noise analysis indicated that current noise regulations can be met with modern baseline blade designs. Improved blades incorporating low-noise features are expected to result in even lower noise levels. This paper describes improvements to the initial assessment, plus a follow-on study using a more advanced open rotor blade design to power the advanced singleaisle transport. The predicted performance and environmental results of these two advanced open rotor concepts are presented and compared.

\section{SUBJECT TERMS}

Counter-rotating propellers; Turboprop engines; Noise prediction (Aircraft)

\begin{tabular}{|c|c|c|c|c|c|}
\hline \multicolumn{3}{|c|}{ 16. SECURITY CLASSIFICATION OF: } & \multirow{2}{*}{$\begin{array}{l}\text { 17. LIMITATION OF } \\
\text { ABSTRACT } \\
\text { UU }\end{array}$} & \multirow{2}{*}{$\begin{array}{l}\text { 18. NUMBER } \\
\text { OF } \\
\text { PAGES } \\
20\end{array}$} & \multirow{2}{*}{$\begin{array}{l}\text { 19a. NAME OF RESPONSIBLE PERSON } \\
\text { STI Help Desk (email:help@sti.nasa.gov) } \\
\text { 19b. TELEPHONE NUMBER (include area code) } \\
\text { 443-757-5802 }\end{array}$} \\
\hline $\begin{array}{l}\text { a. REPORT } \\
\text { U }\end{array}$ & $\begin{array}{l}\text { b. ABSTRACT } \\
U\end{array}$ & $\begin{array}{l}\text { c. THIS } \\
\text { PAGE } \\
\text { U }\end{array}$ & & & \\
\hline
\end{tabular}



